\title{
Onset of Inflammatory Bowel Disease Following Interleukin-17A Inhibitor Treatment
}

\author{
Veli YAZISIZ®i İsmail UÇAR@, Bengisu ASLAN@, Funda ERBASAN@, Mustafa Ender TERZİOĞLU® \\ Department of Internal Medicine, Division of Rheumatology, Akdeniz University Faculty of Medicine, Antalya, Turkey
}

Secukinumab, anti-interleukin (IL)-17A, is a new agent for treating spondyloarthritis. Some cases of new-onset or flare of inflammatory bowel disease (IBD) during secukinumab treatment have been reported. ${ }^{1-6}$ In this article, we present a case of new-onset IBD following secukinumab treatment.

A 45-year-old female patient was diagnosed with ankylosing spondylitis (AS) eight years before. She had symptoms and complaints related to the AS although she had taken non-steroidal antiinflammatory drugs and certolizumab pegol at therapeutic dosages for long-term. Certolizumab pegol was switched to secukinumab $(150 \mathrm{mg} /$ week for four weeks, followed by $150 \mathrm{mg} /$ four weeks). At the sixth week of secukinumab treatment, the patient returned to the hospital and was admitted according to symptoms of abdominal pain, diarrhea, tenesmus, increased bowel movements, and a $3 \mathrm{~kg}$ weight loss in the last 20 days. Abdominal examination showed widespread tenderness in the abdomen and increased bowel sounds. Laboratory test results were presented in Table 1.

Flexible colonoscopy showed aphthous ulcers and erosions in the distal $3 \mathrm{~cm}$ segment of the terminal ileum and deep ulcers in the colon wall and mucosa for each segment, accompanied by normal looking protected areas. After biopsy, findings from the histologic evaluation were consistent with chronic active ileitis and focal active colitis.

New-onset IBD related to secukinumab was diagnosed. The secukinumab treatment was stopped and replaced with methylprednisolone (24 mg/day). Five days after receiving methylprednisolone treatment, her symptoms decreased, and all abnormal clinical findings resolved within three weeks.

Secukinumab failed to reduce disease activity in Crohn's disease (CD) and phase Ila study was terminated prematurely due to higher rates of adverse events compared with placebo. ${ }^{7}$ New-onset or activated IBD cases have also been observed in clinical trials evaluating the efficacy of secukinumab in patients with AS and psoriatic arthritis. A pooled safety analysis showed that events of IBD were uncommon with secukinumab treatment. ${ }^{8}$ Post-marketing registries have found 18 new-onset IBD patients among 1,721 patients using secukinumab. ${ }^{9}$ Also, the incidence of new-onset IBD in biologic databases was higher in patients treated with ixekizumab, another IL-17A inhibitor. ${ }^{9}$

Received: April 14, 2019 Accepted: June 26, 2019 Published online: November 06, 2019

Correspondence: Veli Yazısız, MD. Akdeniz Üniversitesi Tıp Fakültesi İç Hastalıkları Anabilim Dalı Romatoloji Bilim Dalı, 07070 Konyaaltı, Antalya, Turkey. Tel: +90 505 - 2294926 e-mail:drvyazisiz@yahoo.com.tr 
Table 1. Laboratory test results

\begin{tabular}{lcc}
\hline & Patient's sample & Normal \\
\hline Hemoglobin & $8.6 \mathrm{~g} / \mathrm{dL}$ & $12-16 \mathrm{~g} / \mathrm{dL}$ \\
White blood cell & $16.710 \mathrm{~mm}^{3}$ & $4,500-8,500 \mathrm{~mm}^{3}$ \\
Platelet & $434,000 \mathrm{~mm}^{3}$ & $150,000-450,000 \mathrm{~mm}^{3}$ \\
Erythrocyte sedimentation rate & $47 \mathrm{~mm} / \mathrm{hr}$ & $0-20 \mathrm{~mm} / \mathrm{hr}$ \\
C-reactive protein & $14.8 \mathrm{mg} / \mathrm{dL}$ & $0-0.5 \mathrm{mg} / \mathrm{dL}$ \\
Albumin & $4 \mathrm{~g} / \mathrm{dL}$ & $3.5-5.4 \mathrm{~g} / \mathrm{dL}$ \\
Stool (microbiological examination) & Enrichment of erythrocytes and leukocytes. & No erythrocytes leukocytes and parasites. \\
Stool culture & No parasites & Normal colonic bacterial flora \\
Entamoeba histolytica antigen & Normal colonic bacterial flora & Negative \\
Clostridium difficile toxins & Negative & Negative
\end{tabular}

Interleukin-21 and IL-22 produced by T-helper 17 (Th17) cells have protective and regenerative effects on epithelial cells. ${ }^{10}$ Th17 cells can contribute to $\mathrm{CD}$ progression by dysregulating mucosal immunological response. ${ }^{11}$ While Th17 cells have been shown to contribute to the progression of $\mathrm{CD}$, it is interesting that IL-17 blockade drugs have been ineffective in the treatment of that disease.

The therapeutic use of biological agents produces some adverse, undesirable and paradoxical effects. The new onset of IBD in patients taking IL-17A antagonists may similarly result from imbalance in cytokine levels in the bowel. An increasing number of case reports and studies show that IL-17 blockade may have no place in the treatment of IBD.

In conclusion, it should be kept in mind that before starting an IL-17 antagonist on a patient with spondyloarthropathy, signs of subclinical bowel disease should be carefully investigated. Additionally, new-onset IBD may develop in patients using IL-17 blocking drugs for the treatment of other inflammatory diseases.

\section{Declaration of conflicting interests}

The authors declared no conflicts of interest with respect to the authorship and/or publication of this article.

\section{Funding}

The authors received no financial support for the research and/or authorship of this article.

\section{REFERENCES}

1. Uchida S, Oiso N, Komeda Y, Kudo M, Kawada A. Paradoxical ulcerative colitis during treatment with secukinumab for psoriasis. Eur J Dermatol 2018 Nov 13.

2. Fobelo Lozano MJ, Serrano Giménez R, Castro Fernández M. Emergence of Inflammatory Bowel Disease During Treatment with Secukinumab. J Crohns Colitis 2018 May 9.

3. Wang J, Bhatia A, Krugliak Cleveland N, Gupta N, Dalal S, Rubin DT, et al. Rapid onset of inflammatory bowel disease after receiving secukinumab infusion. ACG Case Rep J 2018;5:e56.

4. Ehrlich D, Jamaluddin N, Pisegna J, Padua D. A challenging case of severe ulcerative colitis following the initiation of secukinumab for ankylosing spondylitis. Case Rep Gastrointest Med 2018;2018:9679287.

5. Shiga H, Fukuda S, Iijima K. Interleukin-17A inhibitorinduced Crohn's Disease/Behçet's disease-like lesions. Inflamm Bowel Dis 2017;23:38-9.

6. Vernero M, Astegiano M, Ribaldone DG. New onset of inflammatory bowel disease in three patients undergoing il-17a inhibitor secukinumab: a case series. Am J Gastroenterol 2019;114:179-80.

7. Hueber W, Sands BE, Lewitzky S, Vandemeulebroecke M, Reinisch W, Higgins PD, et al. Secukinumab, a human anti-IL-17A monoclonal antibody, for moderate to severe Crohn's disease: unexpected results of a randomised, double-blind placebo-controlled trial. Gut 2012;61:1693-700.

8. Schreiber S, Colombel JF, Feagan BG, Reich K, Deodhar AA, McInnes IB, et al. Incidence rates of inflammatory bowel disease in patients with psoriasis, psoriatic arthritis and ankylosing spondylitis treated with secukinumab: a retrospective analysis of pooled data from 21 clinical trials. Ann Rheum Dis 2019;78:473-9. 
9. Deodhar AA, Gladman DD, McInnes IB, van Den Bosch F, Shete A, You R, et al. Post-Marketing Safety of Secukinumab in Adult Patients with Psoriasis, Psoriatic Arthritis and Ankylosing Spondylitis: Cumulative Analysis across $>96,000$ Patient-Treatment Years Exposure. Arthritis Rheumatol. 2018;70(Suppl 10). [Abstract] Available from: https://acrabstracts. org/abstract/post-marketing-safety-of-secukinumabin-adult-patients-with-psoriasis-psoriatic-arthritis-andankylosing-spondylitis-cumulative-analysis-across-9- 6000-patient-treatment-years-exposure/

10. Kumar P, Monin L, Castillo P, Elsegeiny W, Horne $\mathrm{W}$, Eddens $\mathrm{T}$, et al. Intestinal interleukin-17 receptor signaling mediates reciprocal control of the gut microbiota and autoimmune inflammation. Immunity 2016;44:659-71.

11. Brand S. Crohn's disease: Th1, Th17 or both? The change of a paradigm: new immunological and genetic insights implicate Th17 cells in the pathogenesis of Crohn's disease. Gut 2009;58:1152-67. 